\title{
Comparison of Heavily Fertilized Congo, Star and Pangola Grass Pastures in the Humid Mountain Region of Puerto Rico ${ }^{1,2}$
}

\author{
Rubén Caro-Costas, José Vicente-Chandler, and Fernando Abruña ${ }^{3}$
}

\begin{abstract}
The productivity of intensively managed pastures of Congo, Star, and Pangola grasses was compared in the mountain region of Puerto Rico under conditions typical of vast areas in the humid topics. Stargrass produced higher weight gains $(1,274 \mathrm{lb} /$ acre $(1,427 \mathrm{~kg} / \mathrm{ha})$ yearly) and had a higher carrying capacity $(2.91 / 600$-lb steers/acre or $7.27 / 273-\mathrm{kg}$ steers/ha) than did Congo or Pangola grasses, which were similar in both these respects. Apparent in vitro digestibility $(66 \%)$ and protein content $(21.1 \%)$ of Stargrass was higher and lignin content $(4.6 \%)$, lower than that of Congo or Pangola.
\end{abstract}

\section{INTRODUCTION}

Stargrass (Cynodon nlemfuensis) ${ }^{4}$ is rapidly becoming the most widely planted pasture grass in Puerto Rico; Pangolagrass (Digitaria decumbens) has been used extensively on the island for many years; but Congograss (Brachiaria ruziziensis) has been planted only on an experimental scale.

Caro, Abruña, and Figarella (2) determined the response of Stargrass (harvested by cutting) to $\mathrm{N}$ fertilization, harvest interval, and cutting height under conditions typical of the humid mountain region. Similar information was obtained for Conograss by Vicente-Chandler et al. (9) and for Pangolagrass by Vicente-Chandler and Figarella (8).

Caro, Vicente-Chandler, and Figarella (5) found that intensively managed Pangola, Guinea, and Napier grass pastures produced similar high beef yields, outyielding molasses and Para grass pasture in the humid mountain region of Puerto Rico. Caro, Abruña, and Vicente (3) found that intensively managed Stargrass pastures outyielded those of Pangolagrass in beef production and carrying capacity. Caro, Vicente-

${ }^{1}$ Manuscript submitted to Editorial Board November 21, 1975.

${ }^{2}$ This paper covers investigations conducted cooperatively between the Agricultural Research Service, USDA, and the Agricultural Experiment Station, Mayagüez Campus, University of Puerto Rico, Rio Piedras, P. R.

${ }^{3}$ Associate Agronomist in cooperation between the Agricultural Experiment Station and the Agricultural Research Service, USDA, and Soil Scientists, Agricultural Research Service, USDA, Rîo Piedras, Puerto Rico, respectively.

'Possibly a Puerto Rico cultivar of Cynodon dactylon. 
Chandler, and Abruna (4) found that intensively managed Pangolagrass pastures responded to application of up to 2,400 lb/acre of 15-5-10 fertilizer $(2,688 \mathrm{~kg} / \mathrm{ha})$ per year. Vicente-Chandler et al. (10) determined the effect of grazing interval and height on yields of Pangolagrass. Vicente-Chandler et al. (7) described the best methods for establishing and managing grasslands in Puerto Rico.

The present study was conducted to compare the productivity of intensively managed Congo, Pangola, and Star grass pastures growing on steep slopes under conditions typical of the humid mountain region of Puerto Rico, in terms of beef production and carrying capacity as well as yields and composition of the forage consumed by the grazing animals.

\section{MATERIALS AND METHODS}

The experiment was conducted over a 2-year period near Orocovis, at an elevation of about $2,000 \mathrm{ft}(600 \mathrm{~m})$ with a mean annual temperature of about $75^{\circ} \mathrm{F}\left(24^{\circ} \mathrm{C}\right)$ and a seasonal variation of less than $10^{\circ} \mathrm{F}\left(4^{\circ} \mathrm{C}\right)$. The soil was Humatas clay (Ultisol) with an average slope of $30 \%$. A complete randomized block design was used with treatments replicated four times. Individual pastures, 1 acre in size, were provided with water and salt. The soil was limed to about $\mathrm{pH} 6.0$, and $500 \mathrm{lb} / \mathrm{acre}(560 \mathrm{~kg} / \mathrm{ha})$ of 15-5-10 fertilizer were applied to all pastures every 3 months.

The pastures were grazed by young Holstein heifers initially weighing about $350 \mathrm{lb}(160 \mathrm{~kg})$ and replaced yearly. A different group of animals grazed the pastures of each grass species in rotation with 7 days of grazing followed by 21 days of rest. The heifers were treated periodically for parasites and received no feed other than that obtained from the pastures. Two "tester" heifers per acre were kept throughout the year and additional animals added as required to consume excess forage, using the "put and take" system.

Each time the heifers were moved from one pasture to another they were weighed. A record was kept of the grazing days and weight gains for each animal and each pasture. The total digestible nutrients (TDN) produced by each pasture were calculated from these data following recommendations of the Pasture Research Committee (1). Carrying capacity was also calculated and expressed in terms of $600-1 b$ steers/acre (273-kg steers/ha).

During the first year of experimentation, eight areas (each $1 \mathrm{~m}^{2}$ ) in each pasture were cut to ground level before and after each grazing and the forage weighed and dried. The amount of dry forage actually consumed by the grazing cattle was determined from these data by difference. The areas cut in each grazing round were rotated to better reflect trampling and grazing effects. 
Before each grazing, 10 forage samples were taken throughout each pasture by plucking to simulate grazing. These samples, which were considered to be typical of the forage consumed by the grazing cattle, were analyzed for crude protein, calcium, phosphorus, silica and lignin. In vitro digestibility of the samples was determined by R. J. Van Soest using his method (6).

During the second year two heifers were kept per acre throughout the year with no additional animals added during seasons of flush growth and only weight gains were determined.

\section{RESULTS AND DISCUSSION}

Table 1 shows that rainfall was low for the area during both years of experimentation, averaging only $54.2 \mathrm{in}(122 \mathrm{~cm})$ with extended dry periods.

TABLE 1.-Monthly rainfall at Orocovis during the 2 years of experimentation

\begin{tabular}{llrrr}
\hline \multicolumn{1}{c}{ Month } & \multicolumn{2}{c}{ First Year } & \multicolumn{2}{c}{ Second Year } \\
\hline & In & Cm & \multicolumn{1}{c}{ In } & Cm \\
September & 2.9 & 7.4 & 10.6 & 26.9 \\
October & 8.9 & 22.6 & 9.0 & 22.9 \\
November & 7.6 & 19.3 & 3.5 & 8.9 \\
December & 4.8 & 12.2 & 3.3 & 8.4 \\
January & 4.2 & 10.7 & 0.6 & 1.5 \\
February & 1.6 & 4.1 & 4.5 & 11.4 \\
March & 2.2 & 5.6 & 2.6 & 6.6 \\
April & 1.8 & 4.6 & 10.3 & 26.2 \\
May & 1.3 & 3.3 & 2.4 & 6.1 \\
June & 1.9 & 4.8 & 2.7 & 6.9 \\
July & 3.0 & 7.6 & 2.1 & 5.3 \\
August & 3.2 & 8.1 & 3.5 & 8.9 \\
\hline Total & 53.4 & 135.6 & 55.1 & 140 \\
\hline
\end{tabular}

Stargrass produced higher weight gain $(1,274 \mathrm{lb} /$ acre or $1,427 \mathrm{~kg} / \mathrm{ha}$ per year) than did Congo or Pangola grasses which averaged $879 \mathrm{lb} / \mathrm{acre}$ (989 kg/ha) weight gain (table 2). Stargrass also produced highest average daily gain per head $(1.29 \mathrm{lb}$ or $.59 \mathrm{~kg})$.

Table 2 also shows that Stargrass produced more total digestible nutrients (TDN) $(9,008 \mathrm{lb} /$ acre or $10,089 \mathrm{~kg} / \mathrm{ha})$ per year and had a higher carrying capacity (2.91 600-lb steers/acre or $7.27273-\mathrm{kg}$ steers/ha) than did Congo or Pangola which averaged only $6,855 \mathrm{lb} /$ acre $(7,678$ $\mathrm{kg} / \mathrm{ha})$ of TDN and a carrying capacity of 2.21600 -lb steers/acre $(5.23$ 273-kg steers/ha). 
This table also shows that Stargrass produced an average of 16,044 lb/acre $(17,969 \mathrm{~kg} / \mathrm{ha})$ of dry forage yearly that was consumed by the grazing cattle compared to $13,687 \mathrm{lb} /$ acre $(15,329 \mathrm{~kg} / \mathrm{ha})$ for Pangola and $11,978 \mathrm{lb} /$ acre $(13,415 \mathrm{~kg} / \mathrm{ha})$ for Congo.

Apparent digestibility of the forage, calculated from the total digestible nutrients utilized by the cattle and the dry forage consumed, averaged $54.4 \%$ for the three grasses (table 2 ). The in vitro dry matter digestibility of Stargrass (table 3) was better than that of both Congo and Pangola grasses at all seasons of the year, averaging $66 \%$. Pangola and Congo grasses had similar apparent dry matter digestibility, averaging $59.5 \%$ for the year. Dry matter digestibility of the grasses did not vary markedly with season of the year.

Table 2.-Productivity of intensively managed Congo, Star, and Pangola grass pastures over a 1-year period at Orocovis

\begin{tabular}{|c|c|c|c|c|c|c|c|c|c|c|c|}
\hline \multirow[t]{2}{*}{ Grass } & \multicolumn{2}{|c|}{$\begin{array}{l}\text { Gain in } \\
\text { weight } \\
\text { yearly }\end{array}$} & \multicolumn{2}{|c|}{$\begin{array}{l}\text { Average } \\
\text { daily gain } \\
\text { per head }^{1}\end{array}$} & \multicolumn{2}{|c|}{$\begin{array}{c}\text { Carrying } \\
\text { capacity } \\
600-1 b^{2} \\
\text { (273-kg) } \\
\text { steers }\end{array}$} & \multicolumn{2}{|c|}{$\begin{array}{l}\text { Total digest- } \\
\text { ible nutrients } \\
\text { yearly }^{3}\end{array}$} & \multicolumn{2}{|c|}{$\begin{array}{l}\text { Forage consumed } \\
\text { by grazing } \\
\text { cattle yearly }\end{array}$} & \multirow{2}{*}{$\begin{array}{c}\begin{array}{c}\text { Apparent } \\
\text { digesti- } \\
\text { bility of } \\
\text { consumed } \\
\text { forage }\end{array} \\
\%\end{array}$} \\
\hline & $\begin{array}{l}\text { Lb/ } \\
\text { acre }\end{array}$ & $K g / h a$ & $L b$ & $K g$ & $\begin{array}{l}\text { Per } \\
\text { acre }\end{array}$ & $\begin{array}{l}\text { Per } \\
h a\end{array}$ & $\begin{array}{l}\text { Lb/ } \\
\text { acre }\end{array}$ & $K g / h a$ & $\begin{array}{l}\text { Lb/ } \\
\text { acre }\end{array}$ & $K_{g} / h a$ & \\
\hline Star & 1,274 & 1,427 & 1.29 & 0.59 & 2.91 & 7.27 & 9,008 & 10,089 & 16,044 & 17,969 & 56.2 \\
\hline Pangola & 913 & 1,023 & 1.18 & 0.54 & 2.26 & 5.65 & 6,996 & 7,836 & 13,687 & 15,329 & 51.1 \\
\hline Congo & 845 & 946 & 1.04 & 0.47 & 2.17 & 5.43 & 6,715 & 7,521 & 11,978 & 13,415 & 56.1 \\
\hline $\mathrm{LSD}^{05}$ & 263 & 295 & 0.11 & 0.05 & 0.36 & 0.90 & 1,135 & 1,271 & 2,772 & 3,105 & N.S. \\
\hline
\end{tabular}

\footnotetext{
${ }^{1}$ For testers cattle which remained on the pastures throughout the year.

${ }^{2}$ One 600-lb (273-kg) steer consumes $8.5 \mathrm{lb}(3.86 \mathrm{~kg})$ TDN daily.

${ }^{3}$ Calculated from body weight, days of grazing and weight gain following recommendations of the Pasture Research Committee (1).
}

${ }^{4}$ Forage consumed

TDN

Table 3 shows that Stargrass had the lowest lignin content at all seasons ( $4.6 \%$ yearly average). Congograss had a lower lignin content (5.3\% yearly average) than Pangola (6.3\% yearly average) at all seasons. Lignin content of the grasses did not vary markedly with season of the year.

All three grasses had similar average silica contents (about 1.5\%) which varied markedly with season of the year (table 3), ranging from .62 to $2.07 \%$ for Stargrass, from .80 to $2.18 \%$ for Pangola, and from .95 to $2.28 \%$ for Congograss. There was a strong tendency for silica content of the grasses to be lower during the seasons of flush growth (May-August).

Stargrass forage consumed by the grazing cattle had a higher crude protein content at all seasons of the year $(21.1 \%$ yearly average) than did 
TABLE 3.-Percent composition of Congo, Star, and Pangola grass samples obtained by plucking to simulate grazing, as affected by season of the year

\begin{tabular}{|c|c|c|c|c|c|c|c|c|c|c|c|c|c|c|c|c|c|c|}
\hline \multirow{2}{*}{ Month } & \multicolumn{3}{|c|}{$\begin{array}{l}\text { Apparent digest- } \\
\text { bility of dry matter }\end{array}$} & \multicolumn{3}{|c|}{ Lignin } & \multicolumn{3}{|c|}{ Silica } & \multicolumn{3}{|c|}{ Crude protein } & \multicolumn{3}{|c|}{ Phosphorus } & \multicolumn{3}{|c|}{ Calcium } \\
\hline & Star & $\begin{array}{l}\text { Pan- } \\
\text { gola }\end{array}$ & Congo & Star & $\begin{array}{l}\text { Pan- } \\
\text { gola }\end{array}$ & Congo & Star & $\begin{array}{l}\text { Pan- } \\
\text { gola }\end{array}$ & Congo & Star & $\begin{array}{l}\text { Pan- } \\
\text { gola }\end{array}$ & Congo & Star & $\begin{array}{l}\text { Pan- } \\
\text { gola }\end{array}$ & Congo & Star & $\begin{array}{l}\text { Pan- } \\
\text { gola }\end{array}$ & Congo \\
\hline Nov./71 & 62 & 56 & 56 & 5.8 & 7.5 & 7.1 & 1.45 & 1.49 & 0.98 & 15.9 & 14.2 & 12.8 & 0.26 & 0.19 & 0.21 & 0.53 & 0.39 & 0.55 \\
\hline Dec. $/ 71$ & 64 & 58 & 57 & 4.9 & 6.5 & 6.1 & 1.81 & 2.00 & 1.85 & 22.4 & 14.0 & 14.4 & 0.29 & 0.20 & 0.30 & 0.57 & 0.39 & 0.61 \\
\hline Jan. $/ 72$ & 65 & 60 & 63 & 4.8 & 6.2 & 5.3 & 1.98 & 2.18 & 2.28 & 22.6 & 17.5 & 18.3 & 0.21 & 0.19 & 0.23 & 0.52 & 0.44 & 0.58 \\
\hline $\mathrm{Feb} . / 72$ & 67 & 54 & 62 & 4.3 & 6.8 & 5.2 & 2.07 & 2.02 & 1.37 & 23.7 & 19.0 & 21.0 & 0.18 & 0.16 & 0.19 & 0.50 & 0.40 & 0.63 \\
\hline Mar. $/ 72$ & 69 & 58 & 65 & 4.1 & 6.1 & 4.7 & 1.69 & 2.11 & 1.66 & 22.9 & 18.4 & 21.9 & 0.16 & 0.15 & 0.25 & 0.59 & $0.4 I$ & 0.64 \\
\hline Apr. $/ 72$ & 66 & 59 & 63 & 4.6 & 6.0 & 4.8 & 2.00 & 2.01 & 2.21 & 21.9 & 18.3 & 21.6 & 0.20 & 0.20 & 0.24 & 0.50 & 0.38 & 0.54 \\
\hline May/72 & 67 & 64 & 60 & 4.5 & 5.2 & 4.9 & 0.74 & 1.57 & 1.41 & 20.5 & 19.2 & 20.7 & 0.18 & 0.15 & 0.22 & 0.47 & 0.33 & 0.51 \\
\hline June/72 & 67 & 61 & 61 & 4.6 & 5.6 & 4.8 & 1.51 & 1.12 & 1.02 & 20.4 & 16.8 & 18.0 & 0.20 & 0.13 & 0.19 & 0.39 & 0.30 & 0.54 \\
\hline July/72 & 65 & 55 & 59 & 4.6 & 6.6 & 4.9 & 0.62 & 0.80 & 1.64 & 18.2 & 13.4 & 15.3 & 0.21 & 0.15 & 0.21 & 0.39 & 0.35 & 0.44 \\
\hline Aug./72 & 66 & 59 & 60 & 4.1 & 6.1 & 4.6 & 0.94 & 1.04 & 0.95 & 22.4 & 14.8 & 15.3 & 0.21 & 0.21 & 0.21 & 0.43 & 0.40 & 0.46 \\
\hline Average & 66 & 58 & 61 & 4.6 & 6.3 & 5.3 & 1.48 & 1.58 & 1.54 & 21.1 & 16.6 & 17.9 & 0.21 & 0.17 & 0.23 & 0.49 & 0.38 & 0.55 \\
\hline
\end{tabular}

"Determined by the "in vitro" method of Van Soest et al. (6). 
Congo or Pangola grass which averaged $17.2 \%$ (table 3 ). It also had a rather uniform protein content throughout the year, which dropped below $20 \%$ only twice. Protein content of Congograss varied considerably throughout the year from a low of $12.8 \%$ in November, when it blooms profusely, to $21.9 \%$ in March-April.

Pangolagrass consumed by the cattle almost always had a lower $\mathrm{P}$ content than did Congo or Star grasses (table 3). Yearly average $\mathbf{P}$ contents were $.17, .23$ and $.21 \%$ for Pangola, Star and Congo grasses, respectively.

Pangolagrass also had a lower Ca content at all seasons of the year than did Congo or Star grasses. Yearly average Ca contents were .38, .55 and $.49 \%$ for Pangola, Congo, and Star grasses, respectively.

During the second year of grazing, when all grasses were stocked with 2 head/acre ( 5 head/ha) throughout the year, the three grasses produced an average of $1,050 \mathrm{lb} /$ acre $(1,176 \mathrm{~kg} / \mathrm{ha})$ per year weight gain (table 4$)$.

TABle 4.-Productivity of Congo, Star, and Pangola grass pastures over a second 1-year period of grazing at Orocovis during which all pastures were stocked at a fixed rate of 2 head/acre throughout the year

\begin{tabular}{lcccc}
\hline Grass & \multicolumn{2}{c}{ Weight gain } & \multicolumn{2}{c}{$\begin{array}{c}\text { Average daily } \\
\text { gain per head }\end{array}$} \\
\hline Lb/acre & $K g / h a$ & $L b$ & $K g$ \\
Pangola & 1,134 & 1,270 & 1.60 & 0.73 \\
Congo & 1,085 & 1,215 & 1.53 & 0.70 \\
LSD $^{0.5}$ & 932 & 1,044 & 1.31 & 0.60 \\
& N.S. & N.S. & 0.12 & 0.05 \\
\hline
\end{tabular}

All the cattle had very high weight gains, but those on Star and Pangola grasses had higher daily weight gains per head (an average of $1.56 \mathrm{lb} / \mathrm{d}$ or $.71 \mathrm{~kg})$ than did those on Congograss which averaged $1.31 \mathrm{lb} / \mathrm{d}(.60 \mathrm{~kg})$. Stargrass was much more susceptible to attacks by the fall army worm (Tophygma frugiperda) than were Congo or Pangola.

\section{RESUMEN}

Se determinó la producibilidad de pastos de las yerbas Congo, Estrella y Pangola cultivados intensivamente bajo condiciones tîpicas de la región montañosa de Puerto Rico y representativos de grandes extensiones en los trópicos húmedos aunque el periodo experimental fue más seco que lo normal para la región.

La yerba Estrella produjo mayores ganancias de peso (1,274 libras por acre ó 1,427 $\mathrm{Kg}$./Ha. el año), y tuvo una mayor capacidad de pastoreo (2.91 novillos de 600 libras de peso por acre ó 7.28 novillos de $273 \mathrm{Kg} . / \mathrm{Ha}$.), que las yerbas Congo y Pangola las que tuvieron producciones similares en estos renglones. La digestibilidad in vitro de la yerba Estrella fue más elevada (66 por 100) y el contenido de lignina más bajo ( 4.6 por 100) que los 
de la yerba Congo y Pangola. La yerba Estrella tuvo un contenido en proteina mayor durante todas las épocas del año (un promedio de 21.1 por ciento durante el año) que las otras yerbas. La yerba Pangola tuvo un contenido más bajo de fósforo y calcio que la Congo y Estrella: El contenido medio en silice de las tres yerbas fue similar.

\section{LITERATURE CITED}

1. Anonymous, - Report on pasture investigations techniques, Joint Comm. Amer. Dairy Sci.Ass., Amer. Soc. Agron., Aner. Soc. Anim. Prod., J. Dairy Sci. 26: 353-69, 1943.

2. Caro-Costas, R., Abruña, F., and Figarella, J., Effect of nitrogen rates, harvest interval and cutting heights on yield and composition of Star grass in Puerto Rico, J. Agr. Univ. P.R. 56 (3): 267-79, 1972.

3. - - - - and Vicente-Chandler, J., Comparison of heavily fertilized Pangola and Star grass pastures in terms of beef production and carrying capacity in the humid mountain region of Puerto Rico, J. Agr. Univ. P.R. 56 (2): 104-9, 1972.

4. — Vicente-Chandler, J., and Abruña; F., The effect of four levels of fertilization on beef production and carrying capacity of Pangola grass pastures in the humid mountain region of Puerto Rico, J. Agr. Univ. P.R. 56 (3): 219-22, 1972.

$5 .-\ldots,-$, and Figarella, $J$., Production of intensively managed pastures of five grasses on steep slopes in the humid mountain of Puerto Rico, J. Agr. Univ. P.R. 49 (1): 99-111, 1965.

6. Van Soest, R. J., Win, R. H., and Moore, L. A., Estimation of the true digestibility of forages by the in vitro digestion on cell walls, Proc. P.R.S. $10^{\text {th }}$ Inter. Grassland Conf. Helsinki, Finland 438, 1960.

7. Vicente-Chandler, J., Abruña, F., Caro-Costas, R., Figarella, J., Pearson, R. W., and Silva, S., Intensive grassland management in the Humid Tropics of Puerto Rico, Agr. Exp. Sta., Univ. P.R., Bull. 233, Feb. 1974.

8. - Figarella, J., and Silva, S., Effect of nitrogen fertilization and frequency of cutting on the yield and composition of Pangola gxass in Puerto Rico, J. Agr. Univ. P.R., 45 (1): 37-45, 1961.

9. — - Silva, S., Abruña, F., and Rodriguez, J., Effect of two cutting heights, four harvest intervals and five nitrogen rates on yield and composition of Congo grass under humid tropical conditions, J. Agr. Univ. P.R. 56 (3): 280-91, 1972.

10. —, - - Rodríguez, J., and Abruña, F., The effect of two heights and three intervals of grazing on the productivity of a heavily fertilized Pangola grass pasture, J. Agr. Univ. P.R. 56 (2): 110-14, 1972. 